\title{
CD7 Gene
}

National Cancer Institute

\section{Source}

National Cancer Institute. CD7 Gene. NCI Thesaurus. Code C38934.

This gene plays a role in T-cell interactions and is a clinical marker for T-cell acute lymphocytic leukemia. 